\title{
Management of Fungi, Pythium aphanidermatum Causing Rhizome Rot Disease of Ginger (Zingiber officinale Rose) in Southern Rajasthan, India
}

\author{
D. K. Jain ${ }^{1}$, Hemant Swami ${ }^{2}$ and R. K. Gangwar ${ }^{3}$ \\ ${ }^{1}$ SMS, Plant Protection, KVK, Udaipur, Rajasthan-313011, India \\ ${ }^{2}$ RCA, MPUAT, Udaipur, Rajasthan-313011, India \\ ${ }^{3}$ Main Rice Research Station, AAU, Nawagam, Kheda (Gujarat), 387540 \\ *Corresponding author
}

\section{A B S T R A C T}

\begin{abstract}
The Field experiments to evaluate the bio efficacy of available market ready fungicides combinations (NATIVO, SAAF, RIDOMIL) and combinations of fungicide viz: Copperoxycloride, Carbendazim, Mencozeb, chloropyriphos (Insecticide), Streptocycline (Bactericide) along with bio control agents (T. viride) was conducted at Talai village of Jhadol block of Udaipur district during year 2016-17 and 201718 to find out an effective control measure against rhizome rot (Pythium aphanidermatum) disease of ginger (Zingiber officinale Rose). The pooled results of two year shows that all the treatments significantly proved superior in decreasing the incidence and severity of the diseases and increasing the germination, tiller number and rhizome yield. The treatment(T8) comprising of Soil treatment with Trichoderma viridae $(3 \mathrm{~kg} / 100 \mathrm{~kg} \mathrm{FYM})+$ Seed treatment (Carbendazim 50\% WP, $2 \mathrm{gm} / \mathrm{kg}+$ Chloropyriphos $20 \%$ EC $1 \mathrm{ml} / \mathrm{kg}$ seed + Streptocyclin $6 \mathrm{gm} / 20 \mathrm{~kg}$ seed ) + Soil drenching with Ridomil gold (Mancozeb $64 \%$ + Metalaxyl $4 \%$ WP $2 \mathrm{~m}$ per litre) and finally seed stored with treatment with (Carbendazim 50\% WP 2 $\mathrm{gm} / \mathrm{kg}$ seed + Chloropyriphos $20 \% \mathrm{EC} 1 \mathrm{ml} / \mathrm{kg}$ seed for next season) proved most effective, which gave $84.23 \%$ mean germination, 17.73 mean number of tillers/plant, $16.28 \%$ mean plant infected and mean yield $14.01 \mathrm{t} / \mathrm{h}$ during year 2016-17 and 2017-18.It was followed by treatment (T6), consisting of Seed treatment (Carbendazim 50\% WP $2 \mathrm{gm} / \mathrm{kg}+$ Chloropyriphos $20 \% \mathrm{EC} 1 \mathrm{ml} / \mathrm{kg}$ ) + Soil drenching with SAAF (Carbendazim $12 \%$ + Mancozeb $63 \%$ WP) @ 2 gm/lit which gave $81.79 \%$ mean germination, 16.33 mean number of tillers/plant, $20.13 \%$ mean plant infected and mean yield $12.98 \mathrm{t} / \mathrm{ha}$., during years 2016-17 and 2017-18 The treatment (T7) consisting of Soil treatment with Trichoderma viridae (3kg / 100 $\mathrm{kg}$ FYM) + Seed treatment (with Trichoderma viridae $(20 \mathrm{~g} / \mathrm{kg}$ seed)+ Soil drenching with Bio-cure (Trichoderma viridae $10 \mathrm{ml} /$ litre water ) proved least effective with minimum $64.18 \%$ mean germination, 13.26 mean number of tillers/plant, $31.68 \%$ mean plant infected and mean yield 7.78 t/ha.All the treatments were found significantly effective over to manage the rhizome rot diseases and ginger yield.
\end{abstract}

Keywords

Rhizome rot, Pythium aphanidermatum. Fungicides, control, Trichoderma

Article Info

Accepted:

18 May 2020

Available Online:

10 June 2020

\section{Introduction}

Ginger (Zingiber officinale Rose) is one of the most important cash and spices crops in India which is now commercially cultivated in nearly every tropical and subtropical country. India is a leading producer in the world (FAO STAT 2016) during 2014-15, produced 0.76 million tonnes from an area of 0.14 million ha. Ginger is extensively cultivated in most of the Indian states, viz. Karnataka, Assam, West Bengal, Madhya Pradesh, Meghalaya, Mizoram, Arunachal Pradesh, Nagaland and Manipur (DASD 2016). Ginger is propagated vegetatively by portions of rhizomes known as seed rhizomes $(20-25 \mathrm{~g})$. The seed rate varies from 1500 to $2500 \mathrm{~kg} / \mathrm{ha}$ seed rhizome in India, 5252 to $7250 \mathrm{~kg} / \mathrm{ha}$ in Southeast 
Asia, 4000-6000 kg/ha in Jamaica and 8000$10000 \mathrm{~kg} / \mathrm{ha}$ in Australia, depending on seed size and spacing (Parthasarathy et al., 2012). In Rajasthan during 2015 -16 it was grown in 13000 hac, with 29000 metric ton production and productivity 2.45 metric ton, while 2016-17 due to rhizome rot disease the area reduced to 11000 hac, with 27000 metric ton production and productivity 2.23 metric ton(Horticulture statistics division, Department of Ag. and cooperation).

Around $90 \%$ of ginger produced in Rajasthan which comes from Jhadol, a tribal-dominated block in Udaipur district. However, during the last 10 years both the area under cultivation and average productivity of ginger have shown a declining trend due to severe rot disease attack. Ginger is a high return but also a high risk crop.

Traditionally, a large number of farmers cultivated ginger in the region, but many gave up its cultivation owing to the frequent rhizome rot disease that destroyed the crops. Ginger is affected by a number of diseases, of which rhizome rot caused by Pythium aphanidermatum is the most prevalent and damaging one (Dohroo 2005).

The pathogen of the disease is both seed and soil-borne and causes huge damage if congenial condition prevails during the growing period. The tip of the leaves turns yellow and the chlorosis proceeds downwards, ultimately resulting in withering and death of the leaf.

The foot of the plant and the rhizomes turn pale. Watery and soft appearance becomes evident on just above the ground level. The rhizomes gradually decompose turning into a decoying mass of tissues enclosed by the comparatively tough rind (Singh, 1978), which causes serious yield reduction. In severe cases it cause complete destroy of crop and yield. Literatures in India and abroad indicate that the disease can be managed by adopting biopesticides, fungicides such as Bavistin, Mencozeb, Trichoderma, Copper oxychloride, etc., (Sharma and Dohroo, 1991; Kim et al., 1998, Ram et al., 1997, Ram et al., 2000, Mathur et al., 2002 and Ayub et al., 2009).

However, in India and also in Rajasthan available information on control of rhizome rot disease of ginger by different method is scanty and the works so far done are preliminary in nature and not conclusive. Under the above circumstances an attempt was made to identify a suitable control method against rhizome rot of zinger using different strategies including, soil treatment, and drenching, even treat the seeds before store with pesticides for next year using as seed, because about 50- 80\% losses during storage have been reported due to this disease (Nirmal,1992).

\section{Materials and Methods}

The field Experiments to evaluate the bio efficacy of nine treatments with available market ready fungicides combinations (NATIVO, SAAF, RIDOMIL) and combinations of fungicide viz: Copperoxycloride, Carbendazim, Mencozeb, chloropyriphos (Insecticide), Streptocyclene (Bactericide) along with bio control agents (T. viride) was carried out at the farmer's field at village Talai, Jhadol block of district Udaipur, Rajasthan, to find out an effective control measure against rhizome rot (Pythium aphanidermatum) disease of ginger (Zingiber officinale Rose during two successive kharif seasons 2016-17 and 2017-18.

The Farmer's fields were selected where previously ginger was infected severely. The Nine treatments with different combinations were tested against the Rhizome rot disease 
caused by Pythium aphanidermatum in ginger with the following treatment schedule:

$\mathrm{T} 1=$ Seed treatment + Soil drenching with SAAF (Carbendazim $12 \%+$ Mancozeb $63 \%$ WP);

$\mathrm{T} 2=$ Seed treatment + Soil drenching with NATIVO (Tebuconazole25\%+Trifloxystrobin $25 \% \mathrm{WP}$ );

$\mathrm{T} 3=$ Seed treatment + Soil drenching with Ridomil gold (Mancozeb $64 \%$ + Metalaxyl 4 $\% \mathrm{WP}$;

$\mathrm{T} 4=$ Seed treatment + Soil drenching with Bavistin (Carbendazim 50\% WP );

$\mathrm{T} 5=$ Seed treatment + Soil drenching with Blitox (Copper oxychloride 50\% WP);

T6 $=$ Seed treatment (Carbendazim 50\% WP + Chloropyriphos $20 \%$ EC) + Soil drenching with SAAF (Carbendazim $12 \%+$ Mancozeb $63 \% \mathrm{WP})$

$\mathrm{T} 7=$ Soil treatment with Trichoderma viridae $(3 \mathrm{~kg} / 100 \mathrm{~kg}$ FYM) + Seed treatment (with Trichoderma viridae (20 g / $\mathrm{kg}$ seed) + Soil drenching with Biocure (Trichoderma viridae $10 \mathrm{ml} /$ litre water);

T8 = Soil treatment with Trichoderma viridae $(3 \mathrm{~kg} / 100 \mathrm{~kg}$ FYM $)+$ Seed treatment (Carbendazim 50\% WP $2 \mathrm{gm} / \mathrm{kg}$ seed + Chloropyriphos $20 \%$ EC $1 \mathrm{ml} / \mathrm{kg}$ seed + Streptocyclin $6 \mathrm{gm} / 20 \mathrm{~kg}$ seed ) + Soil drenching with Ridomil gold (Mancozeb 64 $\%+$ Metalaxyl $4 \%$ WP) and finally seed stored with treatment with (Carbendazim $50 \%$ WP $2 \mathrm{gm} / \mathrm{kg}$ seed + Chloropyriphos 20 $\%$ EC $1 \mathrm{ml} / \mathrm{kg}$ seed for next season), Precaution should be taken that whenever infected plant seen in field, just remove, destroy or burn and drench around two feet periphery of infected plant and uprooted plant.
$\mathrm{T} 9=$ Control

The soil treatment with Trichoderma was done at 7 days before sowing in moist soil. The experiments was conducted in RCBD (Randomized Complete Block Design) with four replications in unit plot size of as $4 \mathrm{X} 4$ $\mathrm{m} 2$ Row to row distance was $30 \mathrm{~cm}$ and rhizome to rhizome distance was $20 \mathrm{~cm}$.. Local ginger variety was used.

The apparently healthy rhizomes were treated with as per treatment before sowing. Rhizomes were dipped in solution for 30 minutes and then dried in shade and sown in the field. In control plots non treated seeds were sown. Soil drenching was started 50 days after planting at the time of diseases initiation and successive soil drenching was applied 4 times at 30 days interval.

The observations on germination(s) was recorded after 30 days of planting, number of tillers was recorded from 10 randomly selected plants from each plot, plant infection (\%) was recorded by counting the number of rhizome rot infected plant per plot, which was recorded after 100 days of sowing and continued up to maturity at 20 days interval, disease severity (0-5 scale) and yield were recorded during two succesecive year kharif 2016-17 and 2017-18 and Pooled data(Mean) of are presented in Table 1.

Disease severity was recorded using a 0-5 scale

Where, $0=$ No infection on rhizome; $1=0.1$ $5.0 \%$ rotting of rhizome; $2=5.1-15.0 \%$ rotting of rhizome; $3=15.1-30.0 \%$ rotting of rhizome; $4=30.1-60.0 \%$ rotting or rhizome; 5 $=$ More than $60 \%$ rotting of rhizome.

The weight of rhizome per plot was recorded and converted into per hectare yield. The data were analyzed statistically for ANOVA and 
treatment means were compared by Duncan's Multiple Range Test (DMRT).

\section{Results and Discussion}

The results show that the all treatments were superior over control and resulted in significant decrease in incidence and severity of the disease and increase in germination, tiller number and rhizome yield as compared to control (Tables 1).

\section{Germination}

The Pooled mean data (Tables 1) of two year ( kharif 2016-17 and kharif 17-18) shows that, the treatment application (T8) consisting of (Soil treatment with Trichoderma viridae $(3 \mathrm{~kg} / 100 \mathrm{~kg}$ FYM $)+$ Seed treatment (Carbendazim 50\% WP, $2 \mathrm{gm} / \mathrm{kg}+$ Chloropyriphos $20 \%$ EC $1 \mathrm{ml} / \mathrm{kg}$ seed + Streptocyclin $6 \mathrm{gm} / 20 \mathrm{~kg}$ seed ) + Soil drenching with Ridomil gold (Mancozeb 64 $\%+$ Metalaxyl $4 \%$ WP@ 2 gm/lit) and finally seed stored with treatment with (Carbendazim 50\% WP $2 \mathrm{gm} / \mathrm{kg}$ seed + Chloropyriphos $20 \%$ EC $1 \mathrm{ml} / \mathrm{kg}$ seed for next season) resulted in maximum germination of rhizomes with 84.56 and 83.90 mean percent germination with pooled mean of 84.23 during kharif 2016-17 and kharif 17-18 respectively, and proved most effective against Rhizome rot disease caused by Pythium aphanidermatum in ginger in terms of percent germination of ginger rhizomes. It was just statistically at par in case of germination by the treatment (T6) consisting of Seed treatment (Carbendazim $50 \%$ WP 2 gm / kg + Chloropyriphos $20 \%$ EC $1 \mathrm{ml} / \mathrm{kg})+$ Soil drenching with SAAF (Carbendazim $12 \%$ + Mancozeb $63 \%$ WP) @ 2 gm/lit] with 81.45 and 82.13 mean percent germination of rhizome with pooled mean 81.79 Percent germination followed with treatment (T3) consisting of (Seed treatment + Soil drenching with Ridomil gold
(Mancozeb $64 \%$ + Metalaxyl $4 \%$ WP) @ 2 gm $/ \mathrm{kg} \quad \mathrm{ST}$ and $2 \mathrm{gm} / \mathrm{lit}$ spray drenching), which gave 78.88 and 77.84 mean percent germination of rhizome with pooled mean 78.36 Percent germination during kharif 2016-17 and kharif 17-18 respectively.

The treatment T7, consisting of Soil treatment with Trichoderma viridae (3kg / $100 \mathrm{~kg}$ FYM) + Seed treatment (with Trichoderma viridae (20 g / kg seed) + Soil drenching with Biocure (Trichoderma viridae $10 \mathrm{ml} / \mathrm{litre}$ water), Proved least effective in terms of percent germination with 64.28 and 64.08 mean percent germination of rhizomes with pooled mean of 64.18 during kharif 2016-17 and kharif 17-18 respectively,. However treatment T2 consisting of NATIVO( Tebuconazole $25 \%+$ Trifloxystrobin $25 \%$ WP); 2 gm per $\mathrm{kg} \mathrm{ST}$ and 2 gm/lit drenching were observed statistically at par with $\mathrm{T} 1$, consisting of [ Seed treatment + drenching with SAAF (Carbendazim $12 \%+$ Mancozeb $63 \% \mathrm{WP}$ ); $2 \mathrm{gm}$ per $\mathrm{kg} \mathrm{ST}$ and $2 \mathrm{gm} / \mathrm{lit}$ drenching]. The order of effectiveness of the treatments, in terms of pooled means germination of ginger rhizomes was observed during kharif 2016-17 and kharif 17-18 in below descending order.

$\mathrm{T} 8(84.23 \%)>\mathrm{T} 6(81.79 \%)>\mathrm{T} 3(78.36 \%)>\mathrm{T} 2(7$ $4.33 \%)>\mathrm{T} 1(69.71 \%)>\mathrm{T} 5(67.11 \%)>\mathrm{T} 4(66.23$ $\%)>\mathrm{T} 7(64.18 \%)>$ and $\mathrm{T} 9(59.33 \%)$.

\section{Tillers per plant}

The observations recorded (pooled) on the number of tiller per plant during the present investigation shows that highest number of tillers per plant was recorded in the treatment (T8) consisting of (Soil treatment with Trichoderma viridae (3kg / $100 \mathrm{~kg}$ FYM) + Seed treatment (Carbendazim 50\% WP, 2 gm $/ \mathrm{kg}+$ Chloropyriphos $20 \% \mathrm{EC} 1 \mathrm{ml} / \mathrm{kg}$ seed + Streptocyclin $6 \mathrm{gm} / 20 \mathrm{~kg}$ seed ) + Soil 
drenching with Ridomil gold (Mancozeb 64 $\%+$ Metalaxyl $4 \%$ WP@ 2 gm/lit) and finally seed stored with treatment with (Carbendazim 50\% WP $2 \mathrm{gm} / \mathrm{kg}$ seed + Chloropyriphos $20 \%$ EC $1 \mathrm{ml} / \mathrm{kg}$ seed for next season) resulted maximum numbers of tillers with 17.74 and 17.42 mean per plant tillers with pooled mean of 17.73 during kharif 2016-17 and kharif 17-18 respectively. It was followed by the treatment (T6) consisting of Seed treatment (Carbendazim $50 \%$ WP $2 \mathrm{gm} / \mathrm{kg}+$ Chloropyriphos $20 \%$ EC $1 \mathrm{ml} / \mathrm{kg})+$ Soil drenching with SAAF (Carbendazim $12 \%+$ Mancozeb $63 \%$ WP) @ $2 \mathrm{gm} / \mathrm{lit}$ ], resulted 16.34 and 16.32 mean per plant tillers with pooled mean of 16.33 during kharif 2016-17 and kharif 17-18 respectively.

It is quite similar with treatment (T3) consisting of (Seed treatment + Soil drenching with Ridomil gold (Mancozeb 64 $\%$ + Metalaxyl $4 \%$ WP) @ 2 gm $/ \mathrm{kg} \mathrm{ST}$ and 2 gm/lit spray drenching), which gave 14.89 and 14.87 mean per plant tillers with pooled mean of 14.88 during kharif 2016-17 and kharif 17-18 respectively. The Number of tillers per plant under treatment, T2 consisting of NATIVO( Tebuconazole $25 \%+$ Trifloxystrobin $25 \% \mathrm{WP}) ; 2$ gm per kg ST and $2 \mathrm{gm} /$ lit drenching) and treatment $\mathrm{T} 1$, consisting of [ Seed treatment + drenching with SAAF (Carbendazim $12 \%+$ Mancozeb $63 \% \mathrm{WP}) ; 2$ gm per $\mathrm{kg}$ ST and 2 gm/lit drenching] statistically at par resulted 13.71 and 13.69 pooled mean per plant tillers during kharif 2016-17 and kharif 17-18 respectively. The treatment T7, consisting of Soil treatment with Trichoderma viridae (3kg / $100 \mathrm{~kg}$ FYM) + Seed treatment (with Trichoderma viridae (20 g / kg seed) + Soil drenching with Biocure (Trichoderma viridae $10 \mathrm{ml} / \mathrm{litre}$ water), Proved least effective in terms of number of tillers with 13.27 and 13.25 mean tillers per plants with pooled mean of 13.26 per plant tiller during kharif 2016-17 and kharif 17-18 respectively.

The order of effectiveness of the treatments, in terms of pooled mean number of tillers per plant was observed during kharif 2016-17 and kharif 17-18, in below descending order.

$\mathrm{T} 8(17.73)>\mathrm{T} 6(16.33)>\mathrm{T} 3(14.88)>\mathrm{T} 2(13.71)>$ $\mathrm{T} 1(13.07)>\mathrm{T} 5(12.78)>$ $\mathrm{T} 4(12.21)>$ $\mathrm{T} 7(13.26)>$ and $\mathrm{T} 9(8.9)$.

\section{Infected Plant (\%)}

The observations on percent infected plants indicated that, The lowest percentage of infected plants was found under the treatments with T8 consisting of (Soil treatment with Trichoderma viridae $(3 \mathrm{~kg} /$ $100 \mathrm{~kg}$ FYM) + Seed treatment (Carbendazim 50\% WP, $2 \mathrm{gm} / \mathrm{kg}+$ Chloropyriphos $20 \%$ EC $1 \mathrm{ml} / \mathrm{kg}$ seed + Streptocyclin $6 \mathrm{gm} / 20 \mathrm{~kg}$ seed ) + Soil drenching with Ridomil gold (Mancozeb 64 $\%+$ Metalaxyl $4 \%$ WP@ 2 gm/lit) and finally seed stored with treatment with (Carbendazim 50\% WP $2 \mathrm{gm} / \mathrm{kg}$ seed + Chloropyriphos $20 \%$ EC $1 \mathrm{ml} / \mathrm{kg}$ seed for next season), resulted in minimum number of infected plant with 16.29 percent and 16.27 percent mean percent with pooled mean of 16.28 percent mean infected plant during kharif 2016-17 and kharif 17-18 respectively, and proved most effective against Rhizome rot disease caused by Pythium aphanidermatum in ginger which was followed by T6 consisting of [Seed treatment (Carbendazim 50\% WP $2 \mathrm{gm} / \mathrm{kg}+$ Chloropyriphos $20 \%$ EC $1 \mathrm{ml} / \mathrm{kg})+$ Soil drenching with SAAF (Carbendazim $12 \%+$ Mancozeb $63 \%$ WP) @ 2 gm/lit] resulted in 20.13 percent and 20.14 percent mean number of infected plant with polled mean of 20.13 infected plant during kharif 2016-17 and kharif 17-18 respectively.Treatement T3 consisting of (Seed treatment + Soil drenching with Ridomil gold (Mancozeb 64 $\%+$ Metalaxyl $4 \%$ WP) @ 2 gm $/ \mathrm{kg} \mathrm{ST}$ and 2 
gm/lit spray drenching) also gave statistically quite similar plant infected percent ( pooled mean 22.11\%) during kharif 2016-17 and kharif 17-18. The efficacy of T. viridae (T7) was identical $(31.68 \%)$ pooled means for two respective season.

The next lowest percentage of pooled infected mean plants was found under the treatments with T2 NATIVO (25.33\%) consisting of ( Tebuconazole $25 \%+$ Trifloxystrobin $25 \%$ WP); 2 gm per kg ST and $2 \mathrm{gm} /$ lit drenching, which was followed by $\mathrm{T} 1(25.02 \%)$ consisting of [ Seed treatment + drenching with SAAF (Carbendazim $12 \%$ + Mancozeb $63 \%$ WP); 2 gm per kg ST and 2 gm/lit drenching] and T5(27.17) consisting of [Seed treatment + Soil drenching with Blitox (Copper oxychloride 50\% WP); 2 gm per $\mathrm{kg} \mathrm{ST}$ and $2 \mathrm{gm} / \mathrm{lit}$ drenching] during kharif 2016-17 and kharif 17-18. In case of control (T7), plant infected \% was maximum of $65.23 \%$ (polled mean) which observed during kharif 2016-17 and kharif 17-18. The efficacy of different treatments was in ascending order:

$\mathrm{T} 8(16.28 \%)<\mathrm{T} 6(20.13 \%)<\mathrm{T} 3(22.11 \%)<\mathrm{T} 2(2$ $5.33 \%)<\mathrm{T} 1(25.02 \%)<\mathrm{T} 5(27.17 \%)<$ $\mathrm{T} 4(28.99 \%)<\mathrm{T} 7(31.68 \%)<$ and $\mathrm{T} 9(65.23 \%)$.

\section{Severity index}

The disease severity index values ranged from 1- 4 (Tables 1). It was 1 under the treatments with T8 consisting of (Soil treatment with Trichoderma viridae (3kg / $100 \mathrm{~kg} \mathrm{FYM)} \mathrm{+}$ Seed treatment (Carbendazim 50\% WP, 2 gm $/ \mathrm{kg}+$ Chloropyriphos $20 \% \mathrm{EC} 1 \mathrm{ml} / \mathrm{kg}$ seed + Streptocyclin $6 \mathrm{gm} / 20 \mathrm{~kg}$ seed ) + Soil drenching with Ridomil gold (Mancozeb 64 $\%$ + Metalaxyl 4\%WP@ 2 gm/lit) and finally seed stored with treatment with (Carbendazim 50\% WP $2 \mathrm{gm} / \mathrm{kg}$ seed + Chloropyriphos $20 \% \mathrm{EC} 1 \mathrm{ml} / \mathrm{kg}$ seed for next season), followed by T6 consisting of [Seed treatment (Carbendazim 50\% WP 2 gm
/ kg + Chloropyriphos $20 \%$ EC $1 \mathrm{ml} / \mathrm{kg})+$ Soil drenching with SAAF (Carbendazim 12 $\%+$ Mancozeb $63 \%$ WP) @ 2 gm/lit] and T3 consisting of (Seed treatment + Soil drenching with Ridomil gold (Mancozeb 64 $\%$ + Metalaxyl $4 \% \mathrm{WP}$ ) @ 2 gm $/ \mathrm{kg} \mathrm{ST}$ and 2 gm/lit spray drenching). ; 2 under T1 consisting of [Seed treatment + Soil drenching with SAAF (Carbendazim $12 \%+$ Mancozeb $63 \%$ WP); 2 gm pe/ kg ST and 2 $\mathrm{gm} /$ lit spray drenching], T2 consisting of [Seed treatment + Soil drenching with NATIVO ( Tebuconazole $25 \%+$ Trifloxystrobin $25 \% \mathrm{WP}) ; 2$ gm per kg ST and $2 \mathrm{gm} / \mathrm{lit}$ spray drenching], T4 consisting of [Seed treatment + Soil drenching with Bavistin ( Carbendazim 50\% WP ); 2 gm per $\mathrm{kg} \mathrm{ST}$ and $2 \mathrm{gm} / \mathrm{lit}$ spray drenching ] and T5 consisting of [Seed treatment + Soil drenching with Blitox (Copper oxychloride $50 \% \mathrm{WP}) ; 2 \mathrm{gm}$ per $\mathrm{kg} \mathrm{ST}$ and $2 \mathrm{gm} / \mathrm{lit}$ spray drenching], and 3 under T. viridie and 4 under control. The pooled data of yield showed (Table 1) that the lowest rhizome yields of $4.07 \mathrm{t} / \mathrm{ha}$ was found under control. The highest rhizome yield of 14.01 t/ha was obtained with T8 consisting of (Soil treatment with Trichoderma viridae (3kg / $100 \mathrm{~kg}$ FYM) + Seed treatment (Carbendazim 50\% WP, $2 \mathrm{gm} / \mathrm{kg}+$ Chloropyriphos $20 \%$ EC 1 $\mathrm{ml} / \mathrm{kg}$ seed + Streptocyclin $6 \mathrm{gm} / 20 \mathrm{~kg}$ seed ) + Soil drenching with Ridomil gold (Mancozeb $64 \%$ + Metalaxyl 4\%WP@ 2 $\mathrm{gm} / \mathrm{lit}$ ) and finally seed stored with treatment with (Carbendazim 50\% WP $2 \mathrm{gm} / \mathrm{kg}$ seed + Chloropyriphos $20 \%$ EC $1 \mathrm{ml} / \mathrm{kg}$ seed for next season), which was statistically similar to T6(12.98 t/ha) and T3(12.65 t/ha).

The lowest yield $7.78 \mathrm{t} /$ ha were obtained with $\mathrm{T}$. viridie (T7). The efficacy of different treatments was in descending order T8 (14.01t/ha.) > T6 (12.98t/ha.) > T3 (12.65t/ha.) $>\mathrm{T} 2 \quad(11.56 \quad \mathrm{t} / \mathrm{ha})>.\mathrm{T} 1 \quad(10.86 \mathrm{t} / \mathrm{ha})>.\mathrm{T} 5$ (9.21t/ha.) > T4 (9.67 t/ha.)> T7 (7.78t/ha.)> And T9 (4.07t/ha.) 
Table.1 Mean Polled data of Effectiveness of different treatment schedule against rhizome rot (Pythium aphanidermatum) of ginger in Jhadol block Udaipur district, Rajasthan during Kharif 2016-17 and Kharif 2017-18

\begin{tabular}{|c|c|c|c|c|c|c|}
\hline $\begin{array}{l}\text { Tr. } \\
\text { No }\end{array}$ & Treatment details & $\begin{array}{l}\text { *Rhizome } \\
\text { germination } \\
(\%)\end{array}$ & $\begin{array}{l}\text { No. of } \\
\text { tillers } \\
\text { /plant }\end{array}$ & $\begin{array}{c}\text { Plant } \\
\text { infected } \\
(\%)\end{array}$ & $\begin{array}{c}\text { Disease } \\
\text { severity } \\
(0-5 \text { scale })\end{array}$ & $\begin{array}{l}\text { Yield } \\
\text { (t/ha) }\end{array}$ \\
\hline $\mathbf{T}_{1}$ & $\begin{array}{l}\text { Seed treatment }(2 \mathrm{gm} / \mathrm{kg})+\text { Soil drenching with } \\
\text { SAAF(2 gm/lit) (Carbendazim } 12 \%+ \\
\text { Mancozeb } 63 \% \mathrm{WP})\end{array}$ & $69.71 \mathrm{c}$ & $13.69 \mathrm{~d}$ & $25.02 \mathrm{~d}$ & 2 & $10.89 \mathrm{c}$ \\
\hline $\mathbf{T}_{2}$ & $\begin{array}{l}\text { Seed treatment }(2 \mathrm{gm} / \mathrm{kg})+\text { Soil drenching with } \\
\text { NATIVO }(2 \mathrm{gm} / \mathrm{lit}) \\
(\text { Tebuconazole } 25 \%+\text { Trifloxystrobin } 25 \% \mathrm{WP})\end{array}$ & $74.33 \mathrm{bc}$ & $13.71 \mathrm{~d}$ & $25.33 \mathrm{~d}$ & 2 & $11.56 \mathrm{c}$ \\
\hline T3 & $\begin{array}{l}\text { Seed treatment }(2 \mathrm{gm} / \mathrm{kg})+\text { Soil drenching } \\
\text { with Ridomil gold }(2 \mathrm{gm} / \mathrm{lit}) \text { (Mancozeb } 64 \%+ \\
\text { Metalaxyl } 4 \% \mathrm{WP}) \text {. }\end{array}$ & $78.36 \mathrm{~b}$ & $14.88 \mathrm{c}$ & $22.11 \mathrm{e}$ & 1 & $12.65 b$ \\
\hline $\mathbf{T}_{4}$ & $\begin{array}{l}\text { Seed treatment }(2 \mathrm{gm} / \mathrm{kg})+\text { Soil drenching with } \\
\text { Bavistin ( Carbendazim 50\% WP })(2 \mathrm{gm} / \mathrm{lit})\end{array}$ & $66.23 \mathrm{c}$ & $12.21 \mathrm{e}$ & $28.99 \mathrm{c}$ & 2 & $09.67 d$ \\
\hline $\mathbf{T} 5$ & $\begin{array}{l}\text { Seed treatment }(2 \mathrm{gm} / \mathrm{kg})+\text { Soil drenching with } \\
\text { Blitox (Copper oxychloride } 50 \% \mathrm{WP}) 2 \mathrm{gm} / \mathrm{lit} \\
\text { spray }\end{array}$ & $67.11 \mathrm{c}$ & 12.78de & $27.17 \mathrm{c}$ & 2 & $09.21 \mathrm{~d}$ \\
\hline T6 & $\begin{array}{l}\text { Seed treatment (Carbendazim 50\% WP } 2 \text { gm / } \\
\text { kg ST + Chloropyriphos } 20 \% \text { EC } 1 \mathrm{ml} \text { per kg } \\
\text { Seed + Soil drenching with SAAF } \\
\text { (Carbendazim } 12 \%+\text { Mancozeb } 63 \% \text { WP) } 2 \\
\text { gm/lit }\end{array}$ & $81.79 \mathrm{a}$ & $16.33 \mathrm{~b}$ & $20.13 \mathrm{e}$ & 1 & $12.98 \mathrm{ab}$ \\
\hline $\mathbf{T}_{7}$ & $\begin{array}{l}\text { Soil treatment with Trichoderma viridae ( } 3 \mathrm{~kg} \text { / } \\
100 \mathrm{~kg} \text { FYM })+ \text { Seed treatment (with } \\
\text { Trichoderma viridae }(20 \mathrm{~g} / \mathrm{kg} \text { seed)+ Soil } \\
\text { drenching with Bio-cure (Trichoderma viridae } \\
10 \mathrm{ml} / \mathrm{litre} \text { water ) }\end{array}$ & $64.18 \mathrm{~d}$ & $13.26 \mathrm{~d}$ & $31.68 b$ & 3 & $07.78 \mathrm{e}$ \\
\hline T8 & $\begin{array}{l}\text { Soil treatment with Trichoderma viridae (3kg / } \\
100 \mathrm{~kg} \text { FYM) + Seed treatment (Carbendazim } \\
50 \% \text { WP } 2 \mathrm{gm} / \mathrm{kg}+\text { Chloropyriphos } 20 \% \text { EC } \\
\text { WP } 1 \mathrm{ml} \text { per kg }+ \text { Streptocyclin } 6 \text { gm per } 20 \mathrm{~kg} \\
\text { seed ) + Soil drenching with Ridomil gold (2 } \\
\text { gm } / \mathrm{kg} \text { ) (Mancozeb } 64 \%+\text { Metalaxyl } 4 \% \mathrm{WP}) \\
\text { and finally put seed treatment with } \\
\text { (Carbendazim } 50 \% \text { WP } 2 \mathrm{gm} / \mathrm{kg} \text { seed }+ \\
\text { Chloropyriphos } 20 \% \text { EC } 1 \mathrm{ml} / \mathrm{kg} \text { seed) }\end{array}$ & 84.23 a & $17.73 \mathrm{a}$ & $16.28 \mathrm{f}$ & 1 & $14.01 \mathrm{a}$ \\
\hline \multirow{4}{*}{ T9 } & Control & $59.33 \mathrm{~d}$ & $8.9 \mathrm{f}$ & $65.23 a$ & 4 & $04.07 a b$ \\
\hline & SEm \pm & 1.68 & 0.360 & 0.80 & & 0.37 \\
\hline & $\mathrm{CD}(\mathrm{P}=\mathbf{0 . 0 5})$ & 4.90 & 1.052 & 2.33 & & 1.07 \\
\hline & $\mathrm{CV}$ & 4.68 & 5.25 & 5.49 & & 7.14 \\
\hline
\end{tabular}


Results of the present investigation showed that T8 consisting of (Soil treatment with Trichoderma viridae (3kg / $100 \mathrm{~kg}$ FYM) + Seed treatment (Carbendazim 50\% WP, 2 gm $/ \mathrm{kg}+$ Chloropyriphos $20 \% \mathrm{EC} 1 \mathrm{ml} / \mathrm{kg}$ seed + Streptocyclin $6 \mathrm{gm} / 20 \mathrm{~kg}$ seed ) + Soil drenching with Ridomil gold (Mancozeb 64 $\%$ + Metalaxyl $4 \%$ WP@ 2 gm/lit) and finally seed stored with treatment with (Carbendazim 50\% WP $2 \mathrm{gm} / \mathrm{kg}$ seed + Chloropyriphos $20 \%$ EC $1 \mathrm{ml} / \mathrm{kg}$ seed for next season), are the most effective treatments to control rhizome rot and to increase rhizome yield of ginger, followed by T6 consisting of [Seed treatment (Carbendazim 50\% WP 2 gm $/ \mathrm{kg}+$ Chloropyriphos $20 \%$ EC $1 \mathrm{ml} / \mathrm{kg})+$ Soil drenching with SAAF (Carbendazim 12 $\%$ + Mancozeb $63 \%$ WP) @ 2 gm/lit] and T3 (Seed treatment + Soil drenching with Ridomil gold (Mancozeb $64 \%$ + Metalaxyl 4 $\% \mathrm{WP}) @ 2 \mathrm{gm} / \mathrm{kg} \mathrm{ST}$ and $2 \mathrm{gm} / \mathrm{lit}$ spray drenching) which gave effective control to the disease and increased rhizome yield.

The effectiveness of fungicides viz, Bavistin, Metalaxyl, Mencozeb, copperoxycloride etc used as seed treatment and soil drenching to control the disease have been reported by other investigators (Dohroo and Sharma, 1983; Ramachandran et al., 1989; Chauhan and Patel, 1990; Das et al., 1990; Choe et al., 1996; Kim et al., 1998; Ram et al., 1999; Mathur et al., 2002) and Ayub et al., 2009. which also confirms the results in present invegition. Two antagonists T. harzianum and T. viridie appeared to be moderately effective to control the disease. More or less similar findings have also been reported by Dohroo and Sharma (1983), Sharma and Dohroo (1991), Ram et al., (1997), Sharma (1998), Ram et al., (1999) and Ayub et al., (2009), they tested different species of Trichoderma against wide range of soil borne fungal pathogens including Pythium spp also similar study was undertaken by Ayub et al., (2009).

\section{References}

Ayub, A., Sultana, N, Faruk, M. I., Rahman, M. M. and Mamun,A. N. M.2009. Control of Rhizome Rot Disease of Ginger (Zingiber officinale Rose) by Chemicals, Soil Amendments and Soil Antagonist. The Agriculturists $7(1 \& 2)$ : 57-61 (2009)

Anonymous, 1999. Statistical Pocket Book of Bangladesh. Bangladesh Bureau of Statistics. Ministry of Planning. Government of Peoples Republic of Bangladesh. $190 \mathrm{p}$.

Camacho H E and Brescia A. 2009. The Australian ginger industry-Overview of market trends and opportunities. The State of Queensland, Department of Employment, Economic Development and Innovation, Australia, p 54.

Chauhan, H. L. and Patel, M. H. 1990. Etiology of complex rhizome rot of ginger in Gujrat and in vitro screening of fungicides against its causal agents. Indian Journal of Agricultural Science. 5(1): 24-25.

Choe, I. Y., Lee, H. H. and. So, I. Y. 1996.Effects of chemicals on growth of Pythium zingiberum causing rhizome rot of ginger and inhibition of disease development. Korean Journal of Plant Pathology, 12(3): 331-335.

Das, T. P. M.; Devadas, V. S. and Pillai, G. R. 1990. Efficiency of fungicides for seed treatment against pre-emergence rhizome rot of ginger. Indian Cocoa, Areca nut and Spices Journal, 14(1): 1315.

DASD. 2016. Spices statistics at a glance 2016, Directorate of Arecanut and Spices Development, Kozhikode, Kerala, p 156.

Dohroo N P. 2005. Diseases of ginger. (In) Ginger: the Genus Zingiber, Medicinal and Aromatic Plants - Industrial Profiles, pp. 305-340. Ravindran P N and Nirmal 
Babu K (Eds). CRC Press, FL.

Dohroo, N. P. and Sharma, S. L. 1983. Evaluation of fungicides for the control of rhizome rot of ginger in storage. Indian Phytopathology, 36(4): 691-693.

FAOSTAT. 2016. http://faostat.fao.org/ (accessed 31.07.2016).

Kim, C. H, Young, S. S. and Hahn, K. D. 1998. Effects of soil disinfection, fungicide application and narrow ridge cultivation on development of ginger rhizome rot caused by Pythium myriotylum in fields. Korean Journal of Plant Pathology, 14(3): 253-259

Mathur K., Ram, P., Poonia, J. and Lodha, B. C. 2002. Integration of soil solarization and pesticides for management of rhizome rot of ginger. Indian Phytopathology, 55(3): 345-347

Nirmal K, Samsuddin K and Ratnambal MJ (1992). Plant, Cell tissue and Organ culture. 29:71-74.

Parthasarathy V A, Srinivasan V, Nair R R, Zachariah T J, Kumar A and Prasath D. 2012. Ginger: Botany and Horticulture. Horticultural Reviews 9: 273-388.

Ram, P., Mathur K. and Iodha, B. C. 1999. Integrated management of rhizome rot of ginger involving biocontrol agents and fungicides. Journal of Mycology and Plant Pathology, 29(3): 416-420.

Ram, P., Mathur K., Iodha, B. C. and Webster, J. 2000. Evaluation of resident biocontrol agents as seed treatments against ginger rhizome rot. Indian Phytopathology, 53(4): 450-454

Ram, P., Mathur, K and Ram, J., 1997. Response of application methods of biocontrol agents either as rhizome pelleting or as soil application or as both against rhizome rot of ginger. Annual Biology. Ludhiana, 13(2): 293296.

Ramachandran, N, Dake, G. N. and Sharma, Y.R. 1989. Evaluation of systemic fungicides for efficacy against rhizome rot of ginger. Indian Phytopathology, 42(4): 530-533.

Sharma, B. K. 1998. Antifungal properties of biocontrol agents and plant extracts against causal fungi of yellows and rhizome rot of ginger. Journal of Biological Control, 12(1): 77-78.

Sharma, S. K. and Dohroo, N. P. 1991. Postharvest management of rhizome rot of ginger through chemical and antagonist. Indian Cocoa, Areca nut and Spices Journal, 14(4): 150-152.

Singh, R.S. 1978. Plant Diseases. Fourth edition. Oxford and IBH Pub. Co., New Delhi $130 \quad$ p. Suresh V N, Venugopalan V V, Beena J, Sreekumar M M and Nirmala A M. 2012. Comparison of essential oil composition of three ginger cultivars from Sub Himalayan region. Asian Pacific Journal of Tropical Biomedicine: S1347-S1350.

\section{How to cite this article:}

Jain. D. K., Hemant Swami and Gangwar, R. K. 2020. Management of Fungi, Pythium aphanidermatum Causing Rhizome Rot Disease of Ginger (Zingiber officinale Rose) in Southern Rajasthan, India. Int.J.Curr.Microbiol.App.Sci. 9(06): 903-911.

doi: https://doi.org/10.20546/ijcmas.2020.906.113 